\title{
PELATIHAN PEMBUKUAN SEDERHANA BAGI WANITA WIRAUSAHA BATIK JONEGORO DI KABUPATEN BOJONEGORO
}

\author{
Nur Laily, Yudi Sidharta, David Efendi \\ Sekolah Tinggi Ilmu Ekonomi Indonesia (STIESIA) Surabaya \\ Corresponding author: nurlaily@stiesia.ac.id
}

\begin{abstract}
The purpose of Community Service Activities Simple Bookkeeping Training for Women entrepreneur batik Jonegoro is able to make simple bookkeeping so that it is orderly in carrying out its financial records so that it can be measured the expenditure, income and profits obtained and can know the progress of the business. The method used by training. The results obtained from this training activity are able to increase entrepreneurial knowledge and skills in making simple bookkeeping so as to increase motivation in work. The conclusion is simple bookkeeping training received a positive response and businesses get knowledge and skills about new insights in running their business through simple financial bookkeeping/recording that is easy to apply.
\end{abstract}

Keywords: Simple Bookkeeping, training. Jonegoro Batik, women entrepreneur. SMEs.

\begin{abstract}
ABSTRAK
Tujuan dari Kegiatan Pengabdian Masyarakat Pelatihan Pembukuan Sederhana bagi wanita wirausaha batik Jonegoro adalah mampu membuat pembukuan sederhana agar tertib dalam melakukan pencatatan keuangannya sehingga dapat terukur pengeluaran, pemasukan dan keuntungan yang diperoleh serta dapat mengetahui perkembangan usahanya. Metode yang digunakan dengan cara pelatihan. Hasil yang diperoleh dari kegiatan pelatihan ini adalah dapat meningkatkan pengetahuan dan keterampilan wirausaha di dalam membuat pembukuan sederhana sehingga meningkatkan motivasi di dalam bekerja. Simpulannya yaitu pelatihan pembukuan sederhana mendapat respons yang positif dan pelaku usaha mendapatkan pengetahuan dan keterampilan mengenai wawasan baru dalam menjalankan usahanya melalui pembukuan/pencatatan keuangan sederhana yang mudah diaplikasikan.
\end{abstract}

Kata kunci: Pembukuan sederhana, pelatihan, batik Jonegoro, wanita wirausaha,UMKM.

\section{PENDAHULUAN}

Kewirausahaan merupakan salah satu faktor pendorong peningkatan perekonomian Indonesia. Kewirausahaan melalui Usaha Mikro kecil menengah diharapkan dapat meningkatkan kreatifitas dan kemampuan masyarakat dalam menyalurkan ide dan kreasinya dengan memanfaatkan sumber daya alam yang tersedia di Indonesia. Usaha Mikro Kecil Menengah (UMKM) di Indonesia merupakan salah satu soko guru perekonomian Indonesia selain koperasi. Hal ini dapat terlihat dari bukti nyata bahwa sebagian besar UMKM di Indonesia tidak menghadapi krisis di tengah tengah krisis global pada tahun 2008 lalu. Perkembangan jumlah UMKM dari tahun ke tahun semakin bertambah. Perkembangan UMKM baru terlihat dari sisi jumlahnya saja. Secara umum, khususnya dalam aspek finansial, hanya sedikit UMKM yang mengalami perkembangan dalam hal kinerja keuangannya. Hal ini tak lepas dari ketidaksadaran pelaku UMKM terhadap pentingnya pengelolaan keuangan perusahaan.

Kabupaten Bojonegoro memiliki banyak potensi usaha yang menjadi sumber mata pencarian utama penduduk di sekitarnya. Mulai dari industri makanan, industri kerajinan, industri tekstil, dan industri agrobisnis semuanya berkembang pesat dan menghasilkan produk komoditas yang memiliki nilai jual cukup tinggi. Saat ini sedikitnya terdapat 112.140 pelaku UMKM yang tersebar di 27 kecamatan yang ada di wilayah kabupaten Bojonegoro. Beberapa diantaranya bahkan tidak hanya sukses memenuhi kebutuhan pasar nasional, namun juga berhasil menembus pesatnya persaingan pasar internasional. Mayoritas pelaku usaha sudah merasa puas dengan hasil yang sudah dicapai saat ini. Beberapa pelaku usaha juga mengalami demotivasi ketika mengalami kendala kendala dalam menjalankan operasional usahanya. Salah satu pelaku UMKM yang saat ini menjadi perhatian pemda Kabupaten Bojonegoro adalah UMKM Batik. Industri kerajinan batik yang terkenal di Kabupaten Bojonegoro yaitu motif batik Jonegoroan. Beberapa kecamatan yang menjadi sentra industri batik daerah tersebut antara lain di Kecamatan Sumberejo, Temayang, Dander, Purwosari, dan Kecamatan Kota Bojonegoro. Sekarang ini sedikitnya terdapat 50 UMKM batik Jonegoroan yang belum cukup tergarap dengan maksimal, sebaliknya banyak pelaku kegiatan UMKM 
Batik (pemilik) justru sering mengalami masalah internal sehingga sulit untuk berkembang dan bersaing baik antara sesama UMKM batik maupun dengan UMKM batik daerah lain seperti batik Solo, Yogyakarta, Pekalongan, Madura dan sebagainya. Masalah pengelolaan keuangan merupakan salah satu masalah yang ditemui di dalam UMKM Batik Jonegoro. Umumnya, pelaku kegiatan UMKM Batik memulai usaha mereka dengan bermodal nekat tanpa dibekali dengan rencana pemodalan jangka panjang maupun kemampuan dan pengetahuan manajerial yang dibutuhkan dalam berwirausaha. Beberapa masalah pengelolaan keuangan umum yang sering dijumpai pada UMKM batik antara lain adalah, Masih tercampurnya keuangan pribadi pemilik dengan keuangan usaha dan buruknya metode pencatatan transaksi yang dilakukan.

Rivai (2013) menyatakan bahwa pencatatan laporan keuangan yang sistematis memiliki manfaat manfaat, yaitu dapat memberikan informasi kas yang dapat dipercaya mengenai posisi keuangan usaha pada suatu saat tertentu, dapat memberikan informasi keuangan mengenai hasil usaha dalam satu periode akuntansi, dapat memberikan informasi yang dapat membantu pihak yang berkepentingan untuk menilai kondisi dan potensi suatu usaha serta dapat memberikan informasi penting lainnya yang relevan dengan pihak yang berkepentingan lainnya. Solusi untuk menjawab permasalahan UMKM batik di Bojonegoro adalah dengan memberikan pelatihan Pembukuan Sederhana. Metode ini adalah sangat mudah dan simple dengan harapan wanita mampu untuk mencatat setiap transaksi keuangan dan mampu untuk memisahkan uang usaha dan belanja rumah tangga.

\section{METODE}

Metode yang dilakukan pada pelaksanaan pengabdian masyarakat adalah sebagai berikut:

1. Melakukan koordinasi dengan Dinas Perindustrian dan Tenaga Kerja Kabupaten Bojonegoro.

2. Melakukan survey lapangan guna melihat kondisi langsung wanita pelaku UMKM batik

3. Menyiapkan materi pelatihan Pembukuan Sederhana

4. Pelaksanaan Pelatihan Pembukuan Sederhana

5. Pendampingan Implementasi Pembukuan sederhana.

6. Evaluasi

Keberhasilan dari pelaksanaan kegiatan ini dilihat dari beberapa indikator yaitu 1.) Kehadiran peserta minimal $80 \%$. 2). Peserta terlibat secara aktif selam mengikuti kegiatan pelatihan. 3) Peserta mampu membuat pencatatan transaksi keuangan.4) Peserta mampu menerapkan Pembukuan Sederhana dalam usahanya.

\section{PEMBAHASAN}

Pelaksanaan pengabdian masyarakat bertujuan untuk: Memberikan pengetahuan pentingnya pencatatan transaksi keuangan dan Membantu pelaku UMKM tertib mencatat setiap transaksi keuangan pada Wanita pelaku UMKM Batik Jonegoro di Kabupaten Bojonegoro.

Pelaksanaan kegiatan Pengabdian Masyarakat dilaksanakan dan dijadwalkan dalam 3 tahap yaitu:

1. Tahap I. Pelatihan Pembukuan sederhana

2. Tahap II. Pendampingan implementasi Pembukuan sederhana, dilaksanakan setelah pertemuan ke I

3. Tahap III. Pendampingan ke 2, yaitu melakukan pendamping dengan survey langsung pada wanita pelaku UMKM yang sudah menerapkan Pembukuan Sederhana.

Pada Tahap I pelaksanaan kegiatan Pengabdian Masyarakat yang dilakukan di UPT Dinas Perindustrian Dan Tenaga Kerja Kabupaten Bojonegoro dihadiri oleh 35 peserta yaitu para wanita pelaku UMKM Batik Jonegoro. Kegiatan ini di buka oleh Ibu Machfudoh Suyoto, Istri Bupati Bojonegoro sebagai Ketua Penggerak PKK Kabupaten Bojonegoro. Acara selanjutnya yaitu penyampaian materi pelatihan kemudian dilanjutkan dengan praktek langsung dengan menggunakan contoh soal. Pada akhir acara pelatihan Tahap I dilakukan evaluasi terhadap pencapaian kemampuan peserta, hal ini dimaksudkan untuk memastikan bahwa setiap peserta memiliki kemampuan sesuai dengan materi pelatihan yang telah disampaikan.

Pada Tahap II. Yaitu Pendampingan, yang dilaksanakan 1 (satu ) bulan setelah kegiatan tahap I yaitu Pelatihan pembukuan sederhana. Pada kegiatan pendampingan ini peserta sudah membawa catatan transaksi usahanya selama satu bulan sejak pertemanan yang pertama. Para wanita, peserta pendampingan sudah mampu untuk mencatat setiap kegiatan transaksi keuangan yang berhubungan dengan usahanya. Pada kegiatan ini bersifat pendampingan dan konsultasi, para wanita langsung menerapkan Pembukuan sederhana pada usahanya. Hasilnya para peserta mampu untuk melaksanakan penerapan Pembukuan sederhana.

Pada Tahap III. Satu bulan setelah kegiatan pendampingan, dilakukan survey langsung ke lokasi tempat usaha batik. Survey dilakukan secara acak untuk melihat dan pendampingan penerapan Pembukuan Sederhana.

Selama kegiatan berlangsung tidak banyak hambatan yang ditemukan. Para wanita peserta pelatihan mampu mengikuti proses pelatihan dan pendampingan dengan baik dan sesuai dengan materi pelatihan yang sudah disampaikan. Para wanita selalu semangat untuk mengikuti pelatihan Tahap I dan Tahap II pendampingan. Pelaksanaan kegiatan pelatihan 


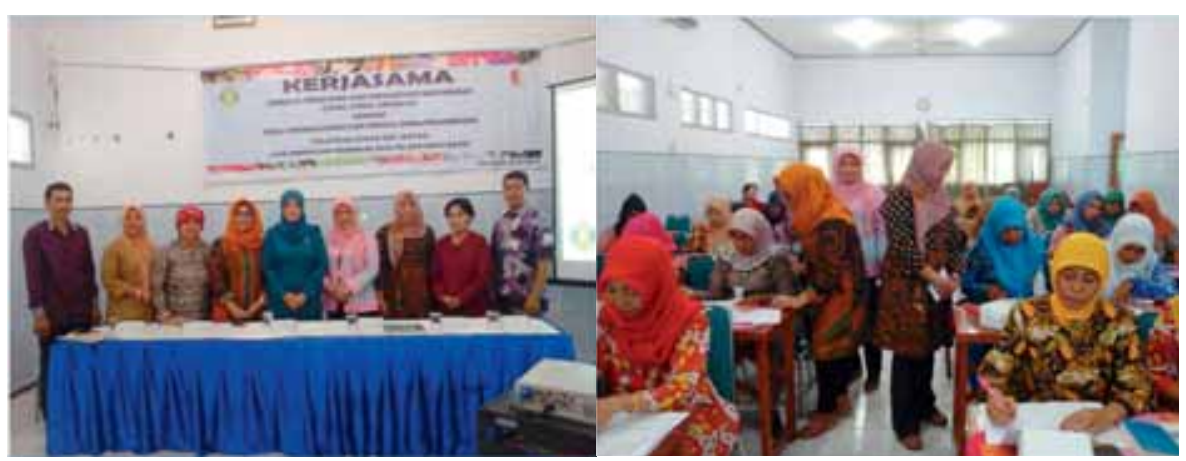

Gambar 1. Pelatihan Pembukuan Sederhana

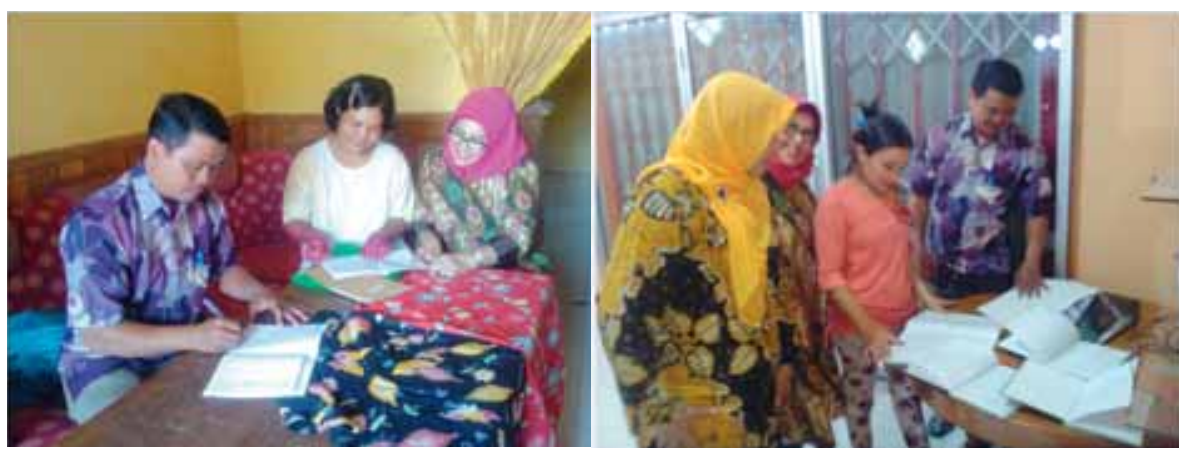

Gambar 2. Pendampingan Implementasi Pembukuan Sederhana

Pembukuan Sederhana ini belum berakhir karena pada tahap berikutnya sudah harus dilakukan pencatatan pada Pembukuan sederhana dengan menggunakan Aplikasi Microsoft Access. Hal ini harus dilakukan karena perkembangan teknologi yang selalu berkembang. Agar para wanita pelaku UMKM usaha semakin berhasil maka sudah harus menggunakan teknologi yang canggih.

\section{PENUTUP}

\section{Kesimpulan}

Sebelum pelaksanaan Pengabdian Masyarakat, para wanita pelaku UMKM batik belum melakukan pencatatan transaksi keuangan. Hal ini karena para wanita menjalankan usaha batik karena ingin menambah penghasilan keluarga dan kegiatan ini dilakukan dirumah tanpa meninggalkan kewajibannya sebagai seorang istri dan ibu rumah tangga. Para wanita ini belum pernah mengenal pencatatan keuangan. Maka kegiatan pelatihan Pembukuan Sederhana ini sangat membantu para wanita dalam mencatat setiap transaksi keuangan yang berhubungan dengan usahanya. Pelaksanaan kegiatan pengabdian masyarakat di Kabupaten Bojonegoro selama 3 Bulan selalu dihadiri $100 \%$ peserta yang sudah diundang. Hasil survey lapangan secara acak pada UMKM batik, mereka sudah menerapkan Pembukuan sederhana untuk kelancaran dan perkembangan usahanya.

\section{Saran}

Perkembangan usaha batik Jonegoro terus berkembang, maka penerapan Pembukuan Sederhana harus dikembangkan. Para wanita wirausaha Batik Jonegoro harus mengikuti perkembangan Teknologi agar tidak ketinggalan dengan industry batik dari daerah lain. Pembukuan sederhana secara manual harus dikembangkan dengan menggunakan Aplikasi Microsoft Access pada Pembukuan sederhana. Untuk memasarkan produk maka harus menggunakan strategi pemasaran produk berbasis online. Peran Dinas Perindustrian Dan tenaga Kerja Pemerintah Daerah Kabupaten Bojonegoro sangat membantu dalam perkembangan industri batik Jonegoro.

\section{UCAPAN TERIMA KASIH}

Penulis mengucapkan terima kasih kepada Ketua STIESIA Surabaya, Kepala Lembaga Penelitian Dan Pengabdian Masyarakat (LP2M) STIESIA Surabaya yang telah memfasilitasi kegiatan Pengabdian Masyarakat di kabupaten Bojonegoro. Ucapan terimakasih juga disampaikan kepada Ibu Bupati Kabupaten Bojonegoro dan Kepala Dinas Perindustrian Dan Tenaga Kerja Kabupaten Bojonegoro beserta staf yang telah memberikan ijin serta fasilitas akomomodasi di Kabupaten Bojonegoro. 


\section{DAFTAR PUSTAKA}

Bojonegoro.Media.(2014). 9 Motif Batik Khas Bojonegoro. https://www.kanalbojonegoro.com/9-motif-batik-khasbojonegoro/March 21.

Hapsari, D.P, Dan Hasanah A.N. (2017). Model Pembukuan Sederhana Bagi Usaha Mikro Di Kecamatan Kramatwatu Kabupaten Serang. Jurnal Akuntasi, 4 (2), 36.

Maulany,T.S., Dialysa.F.,Prawirasasra.K.P. (2016) Pelatihan Pembukuan Keuangan Sederhana Dan Motivasi Kewirausahaan Pada kelompok Usaha makanan RW 02 Kelurahan Neglasari Kecamatan Cibeunying Kaler Bandung. Jurnal Dharma Bhakti STIE Ekuitas 1 (1), p.33
Rivai, V. (2013). Commercial Bank Management: Manajemen Perbankan dan Teori ke Praktik. Edisi 1. Cetakan 1. Jakarta: Rajawali Pers.

Sandika. Rachna (2017) Sejarah Kontemporer Dan Makna 14 Motif Batik Khas Bojonegoro. https://rachnasandika. com/November 27

Subur, R.S. dan M.Hasyim. (2014). Pelatihan Manajemen Keuangan pada pelaku Usaha Toko Kelontongan Dusun Puluhan Desa Banyusidi Pakis Magelang Jawa Tengah. Jurnal Inovasi dan Kewirausahaan, 3 (2), 139. 